\title{
The Development of the Concession Project Management Mechanisms in Regions
}

\author{
Zhanna Mingaleva ${ }^{1}$, Natalia Pazdnikova ${ }^{1}$ \& Elena Alexandrovna Mitrofanova ${ }^{2}$ \\ ${ }^{1}$ Perm National Research Polytechnic University, Russian Federation \\ ${ }^{2}$ State University of Management, Ryazanskiy prospect, 99, Moscow, Russian Federation \\ Correspondence: Zhanna Mingaleva, Komsomolsky Av., 29, Perm, 614000, Russian Federation. E-mail: \\ mingal1@pstu.ru
}

$\begin{array}{lr}\text { Received: August 25, } 2014 & \text { Accepted: September 10, } 2014 \quad \text { Online Published: November 27, } 2014 \\ \text { doi:10.5539/ass.v10n24p257 } & \text { URL: http://dx.doi.org/10.5539/ass.v10n24p257 }\end{array}$

\begin{abstract}
The article reviews the main issues and perspectives of the public-private partnerships in the Russian Federation. The aim of the work is to optimize the region concession project management system for the subject of the Russian federation on basis of the instantiation of concession procedure. The authors suggest the algorithm of concession organization in Perm Krai (region of Russia), taking into account the main components of the concession project management system such as: the objectives, the concept, the objects, the subjects, the factors and the toolset. The main attention is paid on the methodical recommendations on the integral efficiency of the concession project management in the conditions of the economic and social region development. The suggested approach to the region concession management mechanism can be used by the region government to work out the management strategies of concession projects and make out the normative methodical base.
\end{abstract}

Keywords: public-private partnership, the region, concession, management, project, principles, tools, efficiency

\section{Introduction}

The modern social economic development strategy of Russia involves the innovative development and rise of the national economic competitiveness. These goals can be realized only with the using of the new management mechanisms. This tool is public-private partnership (PPP), which is used as well as government contracts in the economic developed countries and in Russia $(32 ; 35)$.

Public-private partnership involves a contract between a public sector authority and a private party, in which there is a realization of public projects in different branches of economy: transport, water and power sectors (7; 15), public utility, construction sector $(36)$, health care $(2 ; 37)$, education (11) and others. The infrastructure concessions have the largest dissemination $(14 ; 23 ; 38)$. Public-private partnership is widely used in solving city's and large agglomeration's development problems $(3 ; 8 ; 20 ; 27)$, urban infrastructure (18), urban regeneration $(6 ; 12 ; 19 ; 21 ; 24)$, urban land-use and revitalization $(5 ; 9 ; 22 ; 31)$, in making large innovative projects in large urban development projects $(10 ; 13 ; 30)$ and others.

The main tool of public-private partnership is a concession, which is used, when the government is interested in a private company to carry out investments in property complexes, but at the same time supposes to keep the right of property. The state strategies and programmes, based on using only budgetary funds, cannot afford to realize the large-scale strategic projects. But the public-private partnership expose the concessionaire a potential risks over the long concession period and the concessionaire may not be able to recover the large initial investment and obtain a reasonable rate of return if significant difficulties occur in the concession period (4; 34). This very actually for Russia.

\section{Background}

The world statistics show that, in the period of 1990-2011 in EU more than 1500 public-private partnership projects, estimated at more than 280 billion Euros were realized. In 2011 more than 110 projects, estimated at more than 20 billion Euros were made, while education and health care amount to $30 \%$. Contractual agreements between public agencies and private companies in the form of public-private partnerships have proven to be beneficial to both the public and private sectors (17). In Russia a concession is used in an infrastructure, urban regeneration, agriculture, public utility and in the sphere of economic security of territory $(16 ; 25 ; 26 ; 28 ; 33)$. 
While the projects, connected with medicine do not take the main place, which is a feature of the developing countries at all. That is why the rise of the development of concession healthcare projects is being expected in the future in the experts' opinion (1). We assign the main development problems and perspectives of a concession in social sphere in the Russian regions and urban territory's by the example of the possibilities assessment of using the concession management mechanisms in the healthcare entities in Perm Krai (region).

Nowadays the relation configuration between a public authority and a private party within the framework of a concession agreement is determined in the legislation of Russia. At the Federal level it is regulated by the federal law N 115 of July 6, 2005 "A concession agreement". At Perm Krai the level of government regulation N 887-p "Making a concession agreement" was adopted on November 13, 2010. There is also the municipal bill of Perm City of October 28, 2008 "The concession agreement in relation to real property of Perm City".

Thus, public-private partnership is statutory in the territory of Perm Krai and is the second widespread form of the interaction between government and private business after government contracts. The issues of using public-private partnership in Russia and in Perm Krai as well were researched earlier in our works. We are going to consider the perspectives of using PPP in the healthcare field.

\section{The Development Innovative Investment Process in Health Care}

The key mechanism of public-private partnership in health care is an innovative investment process activation, which should be supported through:

1) investing in the infrastructure of health care from the different budgets.

2) providing private investors, willing to involve in concession health care projects, with government guarantees

3) attracting the foreign investments through negotiations with potential investors.

4) attracting and organizing brand-new investment, venture funds, involved in a concession partnership.

The realization of the projects with the help of the world medicine equipment manufacturer companies in the territory of Russia allowed to make concession agreements in many regions. In 2009 in the territory of Perm Krai the social infrastructure entities were transferred into concession, and in 2010 the first open competition on transferring a vacant property of 1328.5 sq. $\mathrm{m}$. into a concession agreement was announced. The expected investment is not less than 82.5 million rubles, the reconstruction dates is not more than 240 days on the terms of rendering of the free medical services within the whole concession agreement period.

A concession agreement should be mutually beneficial for both sides. As the result of the project realization the concessor has benefits such as new modern institutions modernization and reconstruction of healthcare institutions. The government keeps the control rights over these institutions during the modernization and reconstruction. Nowadays a concession is divided into three types:

1) the infrastructure entity which cannot be privatized;

2) the new entity or theirs complete modernization;

3) the managing municipal property.

A concessionaire's benefit is an attracting new clients (in the health care field is through making medical insurance). The benefit for people is a probable medical service quality improvement. The main issue of the work is the effective concession procedure organisation problem. Any social economic process has definite stages, which represent management mechanism with the aim of making management decisions to meet the targets. A concession procedure is consisted of four main stages (see Figure 1).

A concession procedure is an ordered activity of the concession management participants, consisted of the definite stages and carried out on the basis of concession projects realization for the purpose of improving the efficiency of a social economic system of a territory (29).

The authors consider a concession project management system as the collection of the interrelated elements of the concession management, which undergoes the successive stages of complication and differentiation in its own development for the purpose of accepting rational management decisions. 


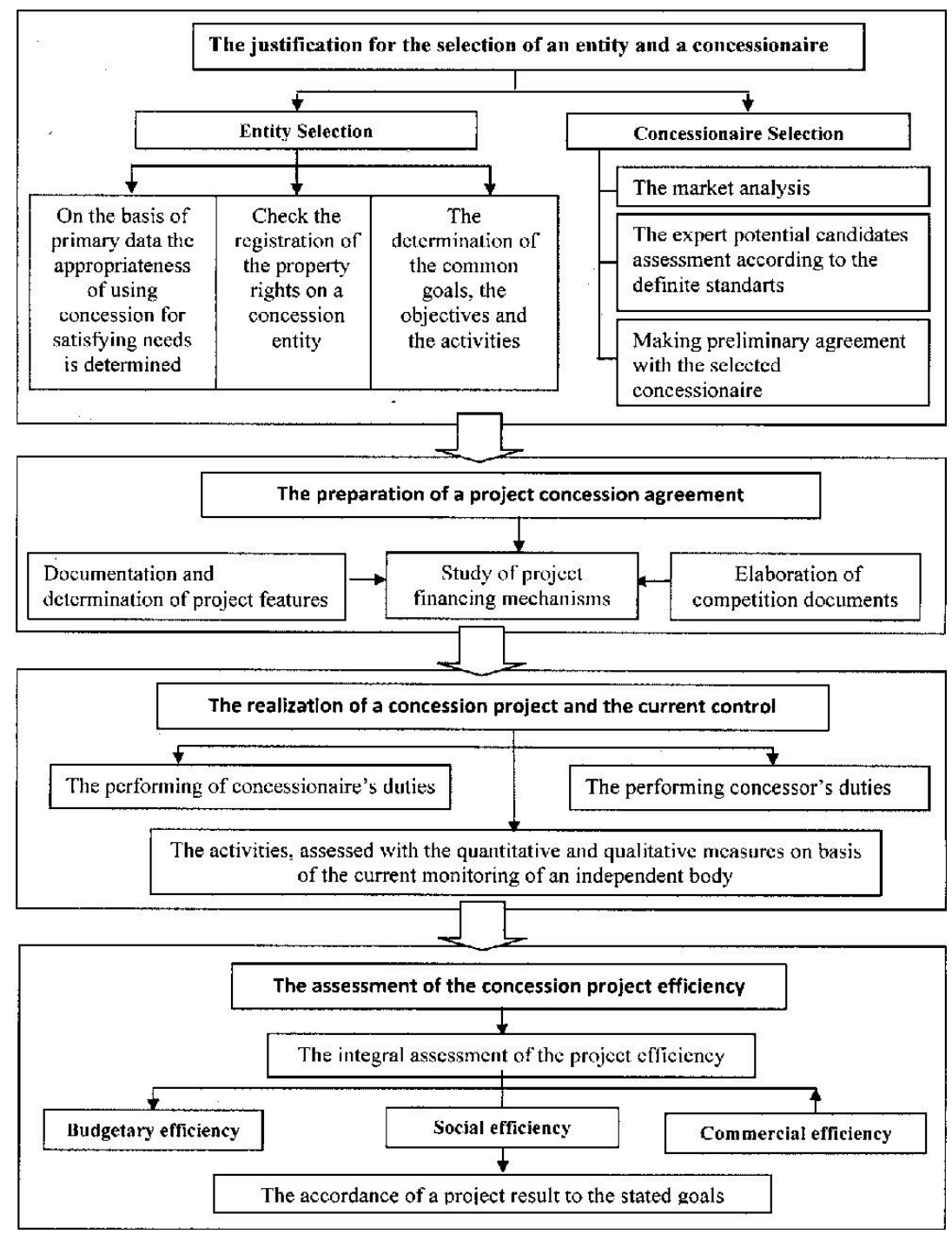

Figure 1. A concession procedure

A concession procedure includes four steps: the justification for the selection of an entity and a concessionaire; the preparation of a project concession agreement; the realization of a concession project and its current monitoring; the assessment of the integral efficiency. The components of the regional concession project management system see in Figure 2.

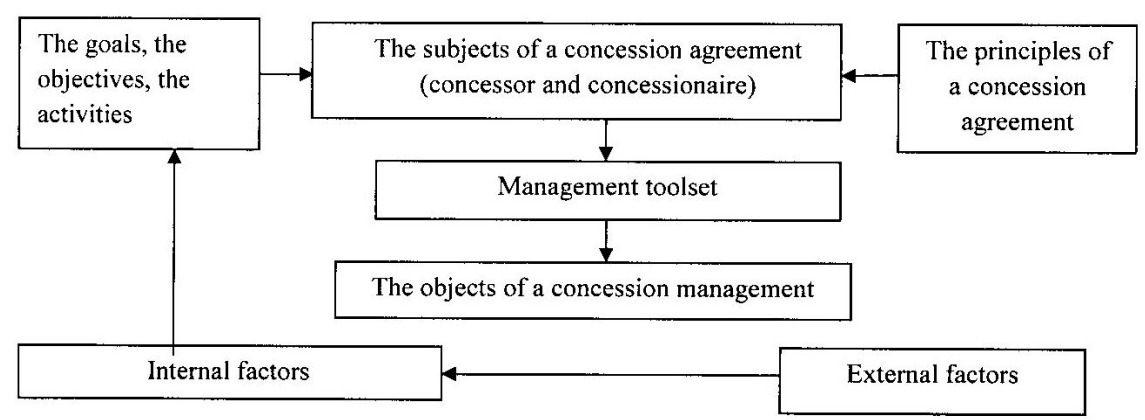

Figure 2. The regional concession project management system 


\section{The Management System of Regional Concession Projects}

Within the framework of systems approach and multi-functionality the authors suggests the system of the regional concession project management with the objectives:

1) determination of priorities of social economic development in the healthcare field;

2) obtaining authentic and impartial information about the activities in the healthcare field by using accounts;

3) determination of system of the measures, defining the effectiveness of stated objectives;

4) determination of the factors, causing risks to the system of healthcare institutions;

5) provision of the available information for the concession agreement participants and publicity.

The main principles of the regional concession project management are: the principle of innovativeness, the principle of priority, the principle of reflection, the principle of continuity, the principle of purposiveness, the principle of system.

Taking into consideration the specific of the healthcare system, the objects of the regional concession project management system are the healthcare infrastructure entity and the vacant hospital and clinic buildings. The subjects are the concession agreement participants- concessor and concessionaire. In Perm Krai concessors can be the Ministry of Healthcare and the Ministry of Property and Land. They are responsible for the regulation in this field and its property complex. They must provide concessionaires with the guarantees in the case of the legislation and tariffs changes, according to those a concessionaire services the consumers. Concessionaires can be the Russian as well as the foreign legal entities, and the entrepreneurs, who are interested in such an agreement in order to get an income.

The full-scale process of the regional concession project management is supplemented with the natural process, the evolution of social economic and political processes, the security threat to society, the development of positive changes, i.e. the factors, which accelerate or hamper the process dynamics.

The main element of any social economic process is the toolset. The regional concession system of management presented with the weak legal and methodical bases. In order to provide the concession with the effective functioning and the further development, the regional authorities must take a number of stimulating measures such as the working out the long-term concept of concession relationships development, included the goal, the objectives, the principles, the mechanisms and the tools of development.

The methodical base should be organized through making up the assessment methods of efficiency of realization of program and other activities, including the assessment of budgetary, social and commercial efficiency. That is why the following should be taken into account:

The budgetary efficiency rate of the projects of concession agreement is determined as the ration of discount tax revenue to the discount volume of investments.

The social efficiency rate is determined as the share of gross regional product volume of the project, being realized within the all years in the subject of the Russian Federation, which can be ensured as the result of concession agreement realization (see Formula 1).

$$
\mathrm{VA}=\mathrm{EBITDA}+\mathrm{Sal}+\text { Rent }
$$

EBITDA is Earnings before Interest, Taxes, Depreciation and Amortization;

Sal is a salary of the members of concession project;

Rent is a concession payment.

The commercial efficiency rate is determined with the help of the net value, the internal rate of return and discounted payback period.

\section{Conclusions}

The conceptual approach of the development of the management system of concession projects of the region anticipates the formation of the mechanisms, consisted of the modules of goals, the principles, the objects, the subjects and the toolset. The functioning of these modules should be focused on the main stages of the concession procedure and the meaning of the project for the region. It is necessary to pay attention to the methodology of the calculation of efficiency of management. It is considered as the considerable tool of the measurement of quality not only of the management of public-private partnership projects, but also of the whole regional economy. 


\section{Acknowledgements}

The work is carried out based on the task \#2014/152 on fulfillment of government contractual work in the field of scientific activities as a part of base portion of the state task of the Ministry of Education and Science of the Russian Federation PNIPU (topic \#1487).

\section{References}

Baig, M. B., Panda, B., Das, J. K., \& Chauhan, A. S. (2014). Is Public Private Partnership an Effective Alternative to Government in the Provision of Primary Health Care? A Case Study in Odisha. Journal of Health Management, 16(1), 41-52. http://dx.doi.org/10.1177/0972063413518679

Buse, K., \& Waxman, A. (2001). Public-private health partnerships: A strategy for WHO. Bulletin of the World Health Organization, 79(8), 748-754.

Chan, A. P. C., Lam, P. T. I., Chan, D. W. M., Cheung, E., \& Ke, Y. (2009). Drivers for adopting public private partnerships-empirical comparison between China and Hong Kong special administrative region. Journal of Construction Engineering and Management, 135(11), 1115-1124. http://dx.doi.org/10.1061/(ASCE)CO. 1943-7862.0000088

Cheung, E., \& Chan, A. P. C. (2012). Risk Factors of Public-Private Partnership Projects in China: Comparison between the Water, Power, and Transportation Sectors. Journal of Urban Planning and Development, 137(4), 409-415. http://dx.doi.org/10.1061/(ASCE)UP.1943-5444.0000086

Cheung, E., \& Chan, A. P. C. (2014). Revitalizing historic buildings through a partnership scheme: Innovative form of social public-private partnership. Journal of Urban Planning and Development, 140(1). Article number 04013005. http://dx.doi.org/10.1061/(ASCE)UP.1943-5444.0000161

Codecasa, G., \& Ponzini, D. (2011). Public-private partnership: A delusion for urban regeneration? Evidence from Italy. European Planning Studies, 19(4), 648-667. http://dx.doi.org/10.1080/09654313.2011.548471

de Brux, J. (2010). The Dark and Bright Sides of Renegotiation: An Application to Transport Concession Contracts. Utilities Policy, 18(2), 77-85. http://dx.doi.org/10.1016/j.jup.2009.07.003

Devkar, G. A., Mahalingam, A., \& Kalidindi, S. N. (2009). Strategies for development of competencies for implementation of urban public-private partnership projects in India. 2nd International Conference on Infrastructure Systems and Services: Developing 21st Century Infrastructure Networks, INFRA 2009. Article number 5397874.

Edelenbos, J., \& Teisman, G. R. (2008). Public-private partnership: On the edge of project and process management. Insights from Dutch practice: The Sijtwende spatial development project. Environment and Planning C: Government and Policy, 26(3), 614-626. http://dx.doi.org/10.1068/c66m

Firsova, A. A. (2012). Directions of development of innovation investment in public-private partnership. Proceedings of the Saratov State University, 12, 67-71.

Gibson, H., \& Davies, B. (2008). The impact of Public Private Partnerships on education: A case study of Sewell Group Plc and Victoria Dock Primary School. International Journal of Educational Management, 22(1), 74-89. http://dx.doi.org/10.1108/09513540810844576

Gore, T. (1991). Public/private partnership schemes in UK urban regeneration. The role of joint enabling agencies. Cities, 8(3), 209-216. http://dx.doi.org/10.1016/0264-2751(91)90060-5

Gualini, E., \& Majoor, S. (2007). Innovative practices in large urban development projects: Conflicting frames in the quest for "new urbanity". Planning Theory and Practice, 8(3), 297-318. http://dx.doi.org/10.1080/14649 350701514637

Guasch, J. L., \& Straub, S. (2006). Renegotiation of infrastructure concessions: An overview. Annals of Public and Cooperative Economics, 77(4), 479-493. http://dx.doi.org/10.1111/j.1467-8292.2006.00316.x

Guasch, J. L., Laffont, J. J., \& Straub, S. (2008). Renegotiation of concession contracts in Latin America. Evidence from the water and transport sectors. International Journal of Industrial Organization, 26(2), 421-442. http://dx.doi.org/10.1016/j.ijindorg.2007.05.003

Hajiyev, P., \& Mingaleva, Z. (2013). Main ways of attracting investments into agriculture and agro-industrial complex of Russia. Life Science Journal, 10(4), 824-829.

Hodge, G., \& Greve, C. (2005). The challenge of public-private partnerships: Learning from international experience. The Challenge of Public-Private Partnerships: Learning from International Experience, 368. http://dx.doi.org/10.4337/9781845428082

Koppenjan, J. F. M., \& Enserink, B. (2009). Public-private partnerships in urban infrastructures: Reconciling private sector participation and sustainability. Public Administration Review, 69(2), 284-296. http://dx.doi. org/10.1111/j.1540-6210.2008.01974.x 
Kort, M., \& Klijn, E. H. (2011). Public-private partnerships in urban regeneration projects: Organizational form or managerial capacity? Public Administration Review, 71(4), 618-626. http://dx.doi.org/10.1111/j.1540 $-6210.2011 .02393 . x$

Kyvelou, S., Marava, N., \& Kokkoni, G. (2011). Perspectives of local public-private partnerships towards urban sustainability in Greece. International Journal of Sustainable Development, 14(1-2), 95-111. http://dx.doi. org/10.1504/IJSD.2011.039640

Leung, B. Y. P., \& Hui, E. C. M. (2005). Evaluation approach on Public-Private Partnership (PPP) urban redevelopments. International Journal of Strategic Property Management, 9(1), 1-16.

Maeda, H., Kitazawa, T., Niwa, Y., Tanaka, H., Matsuo, M., \& Kashihara, S. (2010). Urban design center on public-private-academic partnership in small local city - Urban Design Center Tamura, Tamura city, Fukushima prefecture. AIJ Journal of Technology and Design, 16(32), 339-344. http://dx.doi.org/10.3130 /aijt.16.339

Malone, N. (2005). The evolution of private financing of government infrastructure in Australia-2005 and beyond. Australian Economic Review, 38(4), 420-430. http://dx.doi.org/10.1111/j.1467-8462.2005.00385.x

Mcgreal, S., Adair, A., Berry, J., Deddis, B., \& Hirst, S. (2000). Accessing private sector finance in urban regeneration: Investor and non-investor perspectives. Journal of Property Research, 17(2), 109-131. http://dx.doi.org/10.1080/095999100367949

Mingaleva, Z. A., \& Pazdnikova, N. P. (2007). The development of methods of budget management potential of the region. Economy of Region, 2, 263-267.

Mingaleva, Z., \& Aitkazina, M. A. (2013). Multi-Agent Model for Financing Innovative Projects in Agriculture. World Applied Sciences Journal, 24(2), 222-226.

Mingaleva, Z., \& Balkova, K. (2009). Problems of innovative economy: Forming of "Innovative society" and innovative receptivity. World Academy of Science, Engineering and Technology, 59, 838-843.

Mingaleva, Z., \& Gataullina, A. (2012). Structural modernization of economy and aspects of economic security of territory. Middle East Journal of Scientific Research, 12(11), 1535-1540.

Mingaleva, Z., Gayfutdinova, O., \& Podgornova, E. (2009). Forming of institutional mechanism of region's innovative development. World Academy of Science, Engineering and Technology, 58, 1041-1051.

Mingaleva, Z., Keneshbayev, B., \& Mombekova, G. (2013). Influence of Institutional Factors on Innovations in Grain Production by the Agroindustrial Complex. Life Science Journal, 10(4), 900-904.

Nijkamp, P., van der Burch, M., \& Vindigni, G. (2002). A comparative institutional evaluation of public-private partnerships in Dutch urban land-use and revitalisation projects. Urban Studies, 39(10), 1865-1880. http://dx.doi.org/10.1080/0042098022000002993

Nikitenko, S. M., Gosen, E. V., \& Kovrigina, S. V. (2012). The partnership of business, government and science: Status and prospects. Kemerovo: Siberian Publishing Group.

Pagonis, T., \& Thornley, A. (2000). Urban development projects in Moscow: Market/state relations in the New Russia. European Planning Studies, 8(6), 751-766. http://dx.doi.org/10.1080/713666440

Pantelias, A., \& Zhang, Z. (2010). Methodological framework for evaluation of financial viability of public-private partnerships: Investment risk approach. Journal of Infrastructure Systems, 16(4), 241-250. http://dx.doi.org/10.1061/(ASCE)IS.1943-555X.0000015

Pine, S. A. (2010). The Concession Agreement-a new type of contract in the Russian law. Journal of Russian law, 3, 12-14.

Shen, L. Y., Li, H., \& Li, Q. M. (2002). Alternative concession model for build operate transfer contract projects. Journal of Construction Engineering and Management, 128(4), 326-330. http://dx.doi.org/10.1061/(ASCE) 0733-9364(2002)128:4(326)

Widdus, R. (2003). Public-private partnerships for health require thoughtful evaluation. Bulletin of the World Health Organization, 81(4), 235.

Zhang, X. (2005). Financial viability analysis and capital structure optimization in privatized public infrastructure projects. Journal of Construction Engineering and Management, 131(6), 656-668. http://dx.doi.org/10.1061/(ASCE)0733-9364(2005)131:6(656)

\section{Copyrights}

Copyright for this article is retained by the author(s), with first publication rights granted to the journal.

This is an open-access article distributed under the terms and conditions of the Creative Commons Attribution license (http://creativecommons.org/licenses/by/3.0/). 